化学工場 の 配置 計 画*

小林俊治**

\section{1. 化学工場の妃是計画の概念}

化学工場の配置を考古る場合，全体配置（Overall Layout)、すなわち各装置および付帯設備を含めたすの そ, 装置内の機器の配置 (Unit Layout) と称如らる あのとに大別せられる。これを絵画にたとえれば，前者 は工場全体としてのデッサンであり，後者は部分の決め 方である。すなわちデッサンを決める場合，画面と余白， 額粶, 壁面との調和などを考眆えと同様, 工場の全体配 固もまた将来の計画，隣接地との関保，立地条件など， 単にその工場内の必要条件以外客钼条件を考虑して決 定せらるべきである。ニーットレイフウトは全体配固， すなわちデッサンとの調和と目的に合致するよ5に決め られるべきであって，单に当面の必要性のみを重視し， 隣接装置の安全性, 全工場の将来性を檥牲にすべきでは ない。

従来のわが国化学工業の発展俚自然発生的に执張が続 けられてきたので，大工場においてさえすいわゆる「入 ッ頭式」工場配置であり，その非能率性と不安全性は石 油化学による技術革新時代を迎えるにあたりますますそ の重大性が指摘せられている。

その依って来たるところは工場の建設時に㧊けるレイ フウトに対する理想と夢の欠除と，その後の执張時の都 合主義によるるのと想像せられる。レイフウトの決定は 常に理想と現実をどのように調和させるかの問題であ る。そのためには最初の工場建設時にその骨格「デッサ
ン」が化学工場配置の原理原則に準ぜられた場合には， その後の技術の進歩, 時勢の変化などによる抬張, 変更 に際しても容易に対処でき，常に経済的生産工場として 存在しうる。图-1 の工場配置はその一例で約 60 年以 前, 近藤会次郎氏が浅野総一郎氏の命を受けフメリカに 学び, その基本計画によったものである。

これを以下述へる現代の化学工場の総合配眉の原則之 照合してみた場合その原則に变りはない。筆者が，かか て同工場に勤務していた時代にしばしば外来者から「最 近建てた工場ですか」と問われたことがある。「いや現 存する日本の最古の製油所です」と答えると皆意外に思 われた。設備の個々については最近まで木造の建物、木 骨のタンク，数十年の古い設備が混在しながらなお第 3 者には近代的工場と感せられ，その設備の老朽さと危険 物の整座工場でありながら 60 有余年，その間西山油田 の最盛期を迎え，数次の拻張に上る全力生産を続けなが ら末だ一度も重大火災がなかった。すなわち安全性に対 して，工場全体は道路によって数個の装固地区，製品地 区，付帯設備地区に分割せられ，原油槽は装置と遠く離 れ，製品槽地区は装置地区と道路によって区剽せられて いる。製品地区と倉庫地区は用水地によって防護せら れ，各所の用水池怙よび廃水池は水田を埋立工場敷地と したものであるか，その埋立用土はすべて用水池の土砂 によって行なわれ，夏期以外の冷却水は付近の小川とこ の用水池によってまかなわれている。原油処理設備から

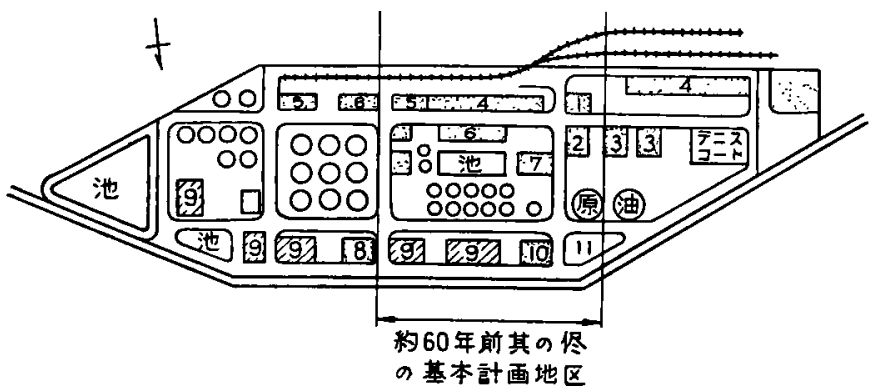

\begin{tabular}{|c|c|c|c|c|}
\hline (1) 事移所 & (5) & 荷造埸 & (C) & 各装炜 \\
\hline (2) 考検室 & (C) & 容器制造场 & (11) & 龙水処理场 \\
\hline 眝藏品金席 & (7) & 㙁理工姆 & (i) & 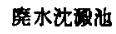 \\
\hline 製品合库 & (1) & 汽午空 & & \\
\hline
\end{tabular}

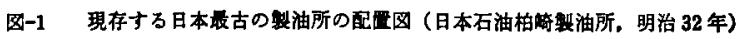

* 昭和 35 年 7 月 1 日受理

** 千代田化工重設株城会社
潤滑油製造設備に至る各装置は西から 東へと一連の流れにそい，中間製品， 製品槽, 出荷設備へと工場の中央に集 的せられている。すなわち工場全体の 作業性と機能性が発揮せられている。 付帯設備の気缶およびポンブ室は装膡 および工場の中間に位直して最短距離 の配管で連絡し，事務所，試験室，詝 蔵品倉庫，修理工場など，管理部門は 工場入口に集団的に配厧せられ，各装 圈, 油槽などと相互の安全と管理部門 の集中化が計られている。

この見事なるブロットブランの原型 が(明治 32 年) 60 年 以前の石油工業 の創始時代にすで行なわれていた。 
この原理原則は現代の化学工業のレイフウトにおいても なんら変りはない。

日本石油業発生時代の先哲の事業に対する熱意と創意 工夫と構想の雄大さは現代においても幾多の学ぶべきす のがある。たと齐ば日本の石油工業地带は港湾埋立地の デルター地帯で地盤沈下が年間 10 湅も予想せられる。 ここの工場建設持汇多量の工事残土の構外搬出をみると き，筆者は浅野総一郎氏の古智によるこの用水池が想い 出されてならない。わが国の化学工場の通念である「八 ッ頭式」自然発生的工場配置, デルター地帯の残土搬出, これと前者を比較してみた場合、「事業主」の工場計画 と「月給取り」の工場計画との盖を発見する。前者は長 期の経営的発展と私財保護からくる安全性の確保の切実 感があ。すなから夢と理想をいかに現実的に画くかの 創意工夫がある。工場計画のデッサンであるレイフウト の問題解決の核心性実にここにある。工場経営の責任あ る者の常に心すべき事柄ではなからうか。

\section{2. 全体配是決定の基本的要点}

化学工場の全体配置を計画する場合，その工場おのお。 のの特性に適用すべきであるがここではその一般的共通 事項に限定して述へることにする。

わが国の化学工業るアメリカのように全化学工業製品 の $70 \%$ が石油化学工業に代ったことく, 石油およびが ス化学工業に移行しつつある。すなわら技術䩢による 産業構造の大変革期にある。石炭化学から石油化学へ，

固体原料から液体扣よびガス原料へ，缓然原料から急然 原料へ、コンベアーからパイブ移送へ，単独装置から連 続装置へと何もかも变りつつある。化学工業のレイアウ トもこの変革炕適応するすのでなければならない。すな わち,

1）安全性飞対する十分なる考虑。

2）計画生産確保付対する精度性能の保持。

3）保全管理を含む生産コストの低減。

4）将来の生産拡大に対する考虙。

5）既設設備の安全性生産性の尊重。

6）接地带飞対する相互調和。

以上の諸項を次の基本的レイフウトについて説明す る。图-2(a) 怔最も基本的の一列配置で共通設䚚る道路 を境として立列に配置する。次期拡張の場合は共通設備 を中央にしてそのまま同形のるのを反対側設ける。大 工場で隣接地を有する場合に適する。图-2(b)は管理機 構々装置の集中化を計ったすので，配管のルーブ化がで き，維持管理に便である。图-2(c)は装置運転の集中管 理を行ならために分析試験および運転管理を行な 5 管理 室を中心に工場全部の施設の中央集中を行なったもので

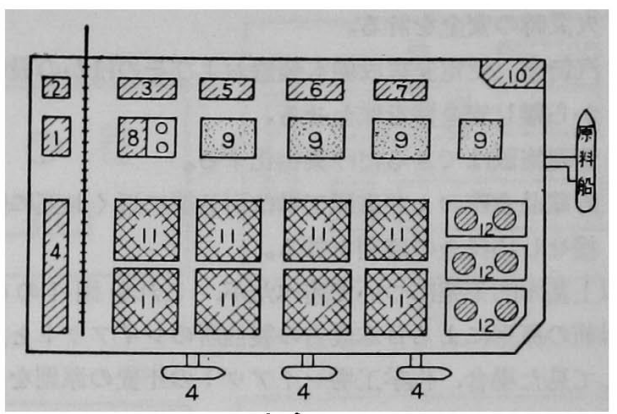

(a)

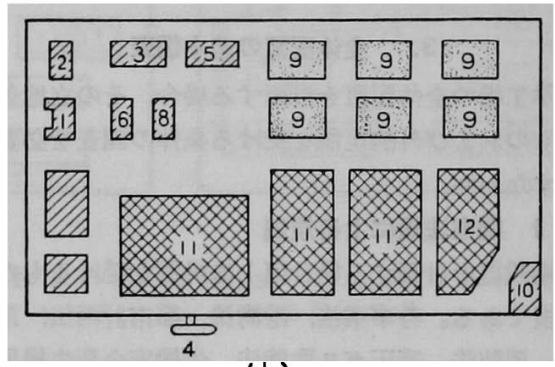

(b)

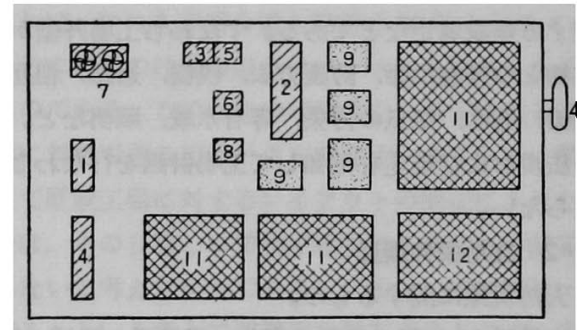
(1) 事稆所
(2) 管理室
(2) 詝藏品倉施

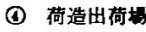
(5) 理工域
(C) 夜归所
(7) 䑪水設佂
(8) 汽年室
(2) 装 相
(10) 排水処理场
(11) 中间扰よび制品棤
(20) 原料格
国-2 化学工㙋の造本的配理

(c)

ある。以上三様の基本形態について共通している事項を 列記すれば，

1）装置地区と製品および原料地区は道路によって分離 せられている(15M 30M)。

2）通路はすべてルーブになっている。

3すナ゙ての設嗝はブロックに区割せられている。

4）装置地区から中問製品地区，製品地区の順に配置せ られ，原料地区は最も遠く離れている。これは配管 の単純化と安全のためである。

5）原料搬入地区と製品出荷地区を区分して相互の搬入 搬出の支障をさける。

6）排水処理設備はできるだけそのほかの設備から離し 
火级時の安全を計る。

7）汽缶室, 受電变電設備も装置およびそのほかの設備 から離し安全性を保たせる。

8）管理施設はできるだけ集中化する。

9）貯藏品倉庫および修理工場は引込線に近く招互に隣 接せしぬ保全の便利を計る。

以上基本的形態について述べたが，これを図-1の60 年以前の原形炕よる日本最古の製油所のレイフウトと比 較して見た場合，化学工場レイアウトの不变の原則を発 見することができる。

\section{3. 全体配置の基本調查}

化学工場の全体配置を計画する場合，その立地策件に よるもの拉よび外的規制を受ける条件の調査を必要とす る。すなわち,

\section{3・1 国家法規による規制}

工場設置を計画する場合第1に規制を受けるものは国 家法規である。各事業法，港海法，都市計画法，市町村 条令, 消防法, 高正ガス取締法, 学㗢安全㦣生規則, 電 気工作物規定，国鉄建設規定なと，関保ある公社公団の 規定する建設規定などである。すなわち工場外壁からの 工作物との保有距離, 防護方法, 栈橋, 通路, 相互の設 直距離，廃水，空気の污染，専有水域，照明など。これ らの法規および規定を熟知して工場計画を行なわなけれ ばならない。

\section{$3 \cdot 2$ 立地条件調查}

1）天然現象に関するもの。

最近 10 力年の気温の变化, 降雨量, 風速, 風向, 湿度, 日照時間などの最高最低の調査, 地震, 潮流, 满潮，干潮，平均水面，水温など。

2）地質および地耐力に関するるの。 ボーリングォよび試験杭，地付力試験を行なら。

3）用水衫上び冷却水，领料水の調查。 成分, 温度, 供給可能量, 価格などの調査。

4）電力および動力の供給量。

5）運搬および道路に関する調查。

\section{$3 \cdot 3$ 地形測量}

平面測量および高低测量を行なう。この場合 $1 / 100$, $1 / 500,1 / 1000$ の各园面和よび付近图を同時に作成する。 この場合，境界点および氷準の原点を設定する。直角座 標間隔は $50 \mathrm{M}$ とする。

\section{4. 道路および工場区囬}

全工場を数個に区劃するが，この大きさは装固の大き さにむよる。通常 $90 \mathrm{M} \times 150 \mathrm{M}$ とし大装置は1区劃1 装置,小型のむのはこの中に 2 装置を配置する。眝蔵槽,
高王装置などは法規の制限があるからこれらによるが， 共通の注意事項を次に示す。

1) 各区㽬は道路によって行な5。

2）主道路は安全のための空間を兼ね $15 \mathrm{M} \sim 30 \mathrm{M}$ ，鋪 装幅は必要に上り決める。

3） 2 次道路は装置の建設保全のために設けられ幅 $6 \mathrm{M}$ 〜8M とする。

4）両者とも行止りであってはならぬ。

5）防壁执よび隣接地との関倸は消防法，高圧ガス取締 法，そのほかの法規に従う。

6) 各装置主要機器と他の区副の機器との距離は通常 $30 \mathrm{M}$ 。常時使用世られる火源からは $30 \mathrm{M}$ 以上。

7) 同一区割内の場合最少 $8 \mathrm{M}$, 火源からは $15 \mathrm{M}$ 以上 とする。

8）道路計画と同時汇配管路の計画を行なろ。

9）配管路恃火災に対して安全を期する空間と防護を必 要とする。

10）近代工場のレイフウト決定の基本は通路と配管路の 整理から始まる。

11）主配管路は計画時に $30 \%$ の余裕を見込む。

\section{5. ユニットレイアウト決定の要点}

ニニットレイフウトを決定する場合次の事項に対して 考虑する。

1）建設時および保全時におけりる作業性に対する空間の 保持, すなわち移動クレーン，ホイスト，機器の分 解, 組立に対する必要空間の保持, ワークウェーの 決定。

2）火源拉よび火災に対する安全性の考虑，すなわち点 火源からの保有距離 (15M 以上), 防壁, 通風, 漏 油の防止とガスの発生防止とその処理。

3) 作業時の必要空間に対する考虑, 機器間の作業空間, 天井空間の検討 (最少 $2.5 \mathrm{M}$ )。

4) 機器の性能保持のための必要条件の検討すなおち ポンブの NPSH と塔槽の液高さ㧊よび圧力の検討。

5）配管拉よび弁数節約のための相互関俰の検討。

6）地形および隣接装置，付带設備との相互の作業性, 安全性に対与る検討。

7）将来の払張および生産增強に対する必要空間扰よび 事前処置の検討。

8）作業員の作業の難易と安全性に対する通路の幅, 階 段の位置の倹討。

9）風水害に对する機械の防護，浸水高さ，防潮方法の 検討。

10）地震に対する架台，電気設㣁などの非常処置方法の 検討。すなわち要約すれば設備機能の保持, 人的お 
よび物的安全性の磼保，短期定期 修理を可能ならしめるための万全 の考庶，才なわち運転稼働率の向 上と運転費の節約，将来の拡張に 対する考虑などにより建設費の 2 重投資を防止すべきである。

\section{6. ユニットレイアウトの基本形態} ニニットレイアゥト決定の基本形態 に数種あるが，これらの組合せおよび 変形またはその装膡の独特の必要に適 応すへきであるがその原則に変りはな W。

1) フローシートの順に並べる方法 小型装固扣よびハイロットブラ ントなどに適用せられ，作業性を 主とし建設費も大した変りはない (図-3 (a) 参照)。

2) 品種別グループの 2 列方式

塔類, 槽類, 熱交類, ポンプ類, 加熱炉, 計器室 を各グループとし，塔槽および荅頂熱交を同一鉄架 台に㯰き，そのほかの熱交を隣接せしめ，ポンプ室 および計画室と 2 並列とする(図-3(b) 参照)。

3）品種別グループの 3 列方式

2）の熱交グループをポンプ列を中央にして 3 列 に並へ，加熱炬を独立配置とする方式（图-3(c)参 照)。

4) テープルトップ方式

鉄筋または鉄骨櫓の上に塔，槽，熱交を固き，そ の下にボンプ室を設け，加熱炉，計器室をその前面 および側面に置く形式である。敷地面積の節約を計 り5るが，建設費は多少高価となる（図-3(d)参 照)。

\section{7. 結 䡒}

以上化学工場の配置計画に対する一般的事項の概要に ついて説明を行なったが, 要するに化学工業は他の産業

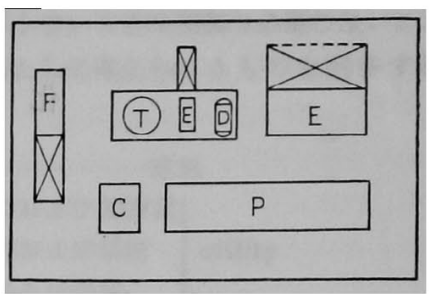

(b) (a)

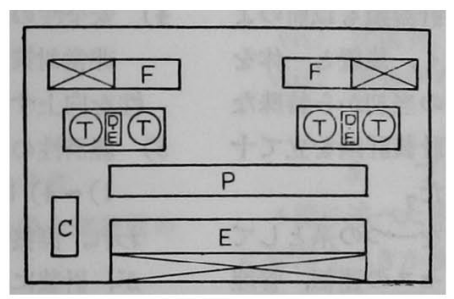

(c)

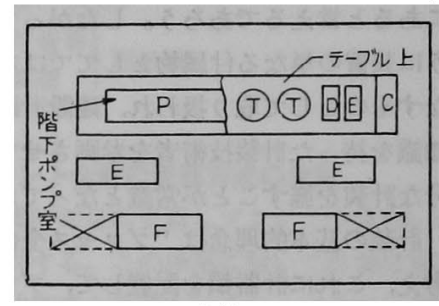

(d)

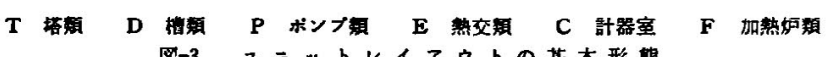

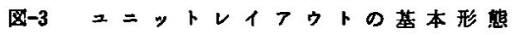

そ比較すると, その災害発生率は昭和 $27 \sim 28$ 年の調査 によれは，他の全産業の重大災害の $30 \%$ を占めている。 加ろるに最近の技術の進歩はブロセスる製品す全く新し いものである。この 2 つの事項すなわち安全性と進歩の 速度に対処できる工場計画を樹立すべきである。筆者が あえて既設工昜に対するレイフウトの問題にふれなかっ たのは，その日暮しの便利主義ではこの 2 つの問題は解 决しないと考えたからである。「新しい酒は新しい皮亚 に盛る」という考えて理想案の青写真の上に古い青写真 を重ね，どこが食い違っているかを発見し，それをどう 現実的に整理するかを考えてみるのが早途である。60年 の日本最古の製油所のブロットプランの説明を最初に行 なったのもこのためである。数カ月前, 京浜間の代表的 な数工場を塔頂から見てこの感を深くした。

わが国の化学工場のレイアウトの問題はまず道路と配 管路の整理から着手しなければならない。すなわちデッ サンを決定し順次現実に合せて根気良くその実現を計る ベきである。 